\title{
Language Attitudes of Jordanian Students Towards English Language
}

\author{
Dr. Ibrahim Fathi Huwari \\ Department of English Language and Literature, \\ College of Arts, Zarqa University, Jordan \\ Author's Emails: ihuwari@zu.edu.jo;ibrahimhuwari@yahoo.com
}

DOI: https://doi.org/10.36941/ajis-2021-0113

\begin{abstract}
This study discussed the language attitudes among EFL students in Jordan society. The present study aimed to investigate the level of language attitude and to discover the relationship between gender, language experience, and the place of learning the language with language attitude. The participants of this study were 300 tenth school students from a private school in Irbid governorate, Jordan. Data was collected through a questionnaire contained 55 statements which were adapted from (Gardener's, 1985). The descriptive analysis used in this research to discover the level of language attitude. T-test and ANOVA were also used to achieve the second research objective. The results of the study revealed that the participants showed a medium level toward learning the language. Female students reported having a higher level of attitude towards learning the language more than male does. Students who learned English at pre-school have more positive attitude compared with others, students who start to learn the language at the age of 6 and below have more positive attitude that the second group. They can speak with more confident way than other groups. Finally, the findings of this study should be used as starting point for both English instructors and students.
\end{abstract}

Keywords: Language attitude, Language experience, EFL, Jordanian students

\section{Introduction}

\subsection{Language}

Language is a tool of communication at the communal and personal levels and is considered as a source of an individual's identity (Oladunni, 2016). Language is a social phenomenon, and its study should stem from the society or context that produced such a phenomenon (Oladunni, 2016). According to Akere (1981), language is the main tool used by humans in their daily functions and social relationships. We communicate through language, and this may create some problematic issues when it comes to delivering the intended meaning or showing our attitudes. Therefore, different conflicts may occur between users of language that might be contributed to the mismanagement of communicative cues used in social interactions. Using a specific form of utterance in the wrong context may lead to miscommunication and misunderstanding. This issue is connected to the nature of language attitude and its relationship to meaning .

Language attitude is related to the explicit behaviour towards language and its users. Each society looks differently at its various dialects and other linguistic forms used by its member. However, multilingual speech communities classify their languages according to the population of 
speakers, usage, and the level of linguistic analysis and so on (Oyetade, 2002). Therefore, languages could be used locally or nationally, or officially while some other languages extend limitations and used as lingua franca or at a regional level. English is considered as the most important means of communication for non-native speakers of English (Al-Khasawneh\&Huwari, 2020). In Jordan, the English learning process is considered a crucial challenge. Although Jordanian students are taught English as a foreign language (EFL) at both the school level and in institutions of higher education, they still find it difficult to master (Al Bataineh, 2019).

\subsection{Language Attitude}

\subsubsection{Definition of Language attitudes}

According to Garrett (2010), defining the concept of attitude is more complicated because of the broad aspects of the term and its dimensions. One definition of language attitude could be found in the Longman Dictionary of Applied Linguistics (1992:199), which states that:

"It is the attitude speakers of different languages, or language varieties have towards each other's languages or to their language. Expressions of positive or negative feelings towards a language may reflect impressions of linguistic difficulty or simplicity, ease or difficulty of learning, degree of importance, elegance, social status and others."

Besides, attitudes comprise three main components: cognitive, affective and behavioural (Garrett, 2010). The cognitive component indicates how attitudes can direct the individual's views toward the surroundings or more specific events. The affective component refers to the emotional side and its relation to the subject of the attitude. The third component refers to the interaction between attitudes and behaviour (Garrett, 2010). Moreover, among the factors affect the attitude, and its strength is the first language of the learner (Baker 1992, as quoted by Llurda 2009: 124) and the kind of formal instruction used in the language (Huguet and Llurda 2001, as quoted by Llurda 2009: 124).

Attitudes are generally connected to other psychological aspects, such as values, habits, opinions, beliefs, ideologies and social stereotypes (Garrett 2010). Gardner's (1985) definition of attitudes shows the strong connection between attitudes and opinions and beliefs. He states that attitude is "an evaluative reaction to some referent or attitude object, inferred based on the individual's beliefs or opinions about the referent" (Gardner, 1985:9). Moreover, Garrett (2010: 30-35) provided different definitions of similar terms by comparing them to attitudes. Habits, for example, are similar to attitudes but differ in their direct reflection of behaviour while attitudes reside in the mind of an individual.

Another example of values, which are defined as "more global and general than attitudes" (Oskamp, 1977, as cited in Garrett 2010: 31), but can assist in forming attitudes. Beliefs are also different from attitudes in not being affective, but are, in fact, "the cognitive component of attitudes" (Garrett 2010: 31). Attitudes and opinions are close concepts but are used similarly in daily speech (Baker 1992: 14, as cited in Garrett 2010: 32), but there is an ability to express opinions directly by the individual while attitudes are more in-depth and may not be expressed directly (Garrett 2010: 32 ). Social stereotypes are defined as forming generalizations about similar people in a specific society or creating differences between different groups. This concept related to language attitudes in the way people relate the accent of the speaker to a specific social group. Finally, language ideology is a concept based on the values related to languages and varieties. According to Garrett (2010:34), strong language ideologies can affect attitudes profoundly. Attention must be paid to the interchangeable usage of the terms mentioned above and their difference.

Social psychology determines the definition of attitude (Malessa, 2011). Howard Gardner is one of its scholars, who was a pioneer in the field of affective factors in language learning. Therefore, the 
definition used in this study is based on Gardner's definition as defined above. Moreover, Gardner's definition of attitude helps us to understand the general or specific attitudes (Gardner 1985). For example, attitudes of a person toward a foreign language can be classified as general while those a person holds for a specific language are specific.

\subsubsection{The Perspective of Language Attitudes}

In the last 50 years, researchers started to have more interest in language attitude because of the importance of the topic to understand the thinking process of humans (Saidat, 2010). Language became more complicated than a mere tool of communication as it helps to unravel many aspects of human nature. A person's attitudes are essential traits of characters and language as a tool of expression, and the choice of words may lead the person to reveal these attitudes or hide them from others. Therefore, research always attempts to explore the link between language and attitudes to reach facts and in-depth analysis of such issues that is based on the genders, ages, ethnic groups, social networks (Saidat, 2010).

Moreover, language is the primary construct of human identity by which we communicate and express our thoughts on purpose or without even thinking of what we utter. For example, a female's way of speaking and using specific phrases may lead us to recognize her social class or some aspects of her personality. According to Gardner (1985), there are three types of language attitudes. The first type is related to the attitudes towards a language community, in which people have attitudes towards other groups or other languages, and thus may relate to authoritarianism or ethnocentrism. The second type is attitudes towards a language. This type entails having attitudes towards language learning or some specific skills of a language, such as reading or writing. The third type is related to attitudes toward the learning context, such as the methods used by teachers or the choice of taught curricula and materials. The latter type can affect the learning process if the only contact between the learner and the second language is inside classrooms but might be less influential if the student is studying abroad.

Experience plays an essential role in developing a person's attitudes and linguistic behaviour (Agheyisi \& Fishman, 1970). Baker (1992) argues that human behaviour takes a specific direction, which could explain with the help of understanding the theoretical concept of the attitude. Therefore, any language attitude is the result of a person's stand toward a language and its speakers, which could be positive or negative. Domains and diglossia are good examples for the formation of language attitudes, where communities that have such features provide an individual with options to follow one language over another and eventually lead to the development of unique linguistic composition to match the communicative needs (Fishman, 1972). The persisted language attitudes are also passed from generation to the next in any given society and become part of the subconsciousness of people. Language attitudes have started for two main reasons. The first is the tendency to reveal and understand value judgments, and the second is related to understanding the impact of negative attitudes of a specific language in a given society (Fishman, 1972).

There is a general agreement in the literature on the person's ability to acquire a language faster and easier when he/she has positive attitudes to the new language and its speakers (Garrett, 2010; Zhang and Slaughter-Defoe, 2009). Language attitudes play a vital role in shaping the reactions to language users and help in predicting the reactions of others to the way this language is used (Garrett, 2010). Baker (1992) and Holmes, Roberts, Verivaki, and Aipolo (1993) argue that language attitudes are also crucial in shifting or maintaining the language. For example, Baker (1992) states that "in the life of a language, attitudes to that language appear to be important in language restoration, preservation, decay or death" (9). Moreover, Holmes et al. (1993) provided examples of the impact of language attitudes over different levels of language shift and maintenance among "Tongan, Greek and Chinese communities in New Zealand". They also discovered that having positive attitudes will motivate the users of the minority language to keep using their language when it exists in a multilingual community, which in turn helps in preserving this minority language from being 
shifted to the primary language of that community. Therefore, preserving language is challenged with the existence of negative attitudes towards this language in any society. However, other researchers, such as Fishman (1972) believes that language attitudes may not be directly indicative of language maintenance or shift because of the importance of linking a language to its impotence and its core value among specific groups that could stem from religious or other beliefs .

Studying attitudes is complicated because of the whole concept it a "psychological construct" (Garrett, 2010:20) or a state of mind. Therefore, it is essential to remember that attitudes received from a person or a group of people may not be a real reflection of their accurate opinions. Baker (1992) argues that when people asked about their attitudes toward something, they may shape a kind of attitudes that appeal to the listener, especially if asked in interviews and questionnaires .

Garrett (2010) argues that there are three methods of viewing and exploring attitudes: societal treatment studies, direct and indirect measures. The first two methods rely on using multiple techniques to investigate attitudes to language directly while the indirect approach depends directly on the matched-guise method. Societal treatment studies extract information about people's attitudes from documented sources, such as written documents, the different means of media, advertisements and other different sources. On the other hand, direct measures depend on engaging people directly by asking them about their language attitude through questionnaires, interviews and surveys, which also referred to as evaluation preference (Garrett, 2010). The indirect method relies on extracting data about people's language attitudes indirectly by using indirect methods, such as the matched-guise technique. The direct approach is frequently used in this field and more common than the indirect approach and the societal treatment technique (Garret, 2010). The exploration of attitudes is essential to this study because the researchers are particularly interested in their participants' attitudes toward English language and its users. The researcher will use direct measures through questionnaires, which will be explained in the methodology section.

\subsubsection{Previous Research}

Many researchers have investigated language attitudes on single languages such as English. Besides, different ESL/EFL contexts have been investigated, such as Malaysian, Iranian, Finnish, United Arab Emirates, and Jordanian. The results of most research such as Al Noursi (2013) in the United Arab Emirates; Al- Tamimi \& Shuib (2009) in Yemen; Al Samadani \& Ibnian (2015) Saudi students; Leppänen, et al. (2011) in Finnish found in their studies that the participants have a positive attitude towards learning English.

The level of attitude towards learning English is varied. A study done by Zainol Abidin, Mohammadi \& Alzwari (2012) discovered the level of attitude among Libyan secondary school. They found that students showed negative attitudes towards learning English. Another study done by Ahmed (2015) investigated 238 undergraduate students at a public university in Malaysia towards English learning and to discover the causes that might have to affect their learning. The results showed that students had negative feelings toward learning the language because of the classroom instructions, domains of usage and focus of learning skills.

However, in the Jordanian context, the level of attitude was varied between moderate to high. A study was done by Momani (2009) on Jordanian High School students discovers students' attitude towards English. The results showed that Jordanian students had a moderate level of attitude towards learning English. In contrast, other research in Jordanian context such as Abu-Snoubar (2017); Al-Khasawneh \& Al-Omari (2015); Tahaineh \& Dana (2013); Saidat (2010) showed that Jordanian students had a positive attitude towards learning English. For example, a study done by Abu-Snoubar (2017) aims to discover the attitudes toward English among students at Al-Balqa Applied University in Jordan. The researcher used Attitude Motivation Test Battery (AMTB) questionnaire adapted from gardener's (1985). The participants of this study were 176 students from different faculties. The results showed that students had positive attitudes towards learning English.

A study done by Rababah (2019) investigated the collaborative learning strategies among EFL 
Jordanian teachers. The sampling was 10 EFL teachers based on the convenience sampling. Interviews and observations were used in this research. The interview results revealed that the participating teachers expressed their opinions on how they used collaborative learning strategy for promoting their students' creativity in EFL writing. Classroom observations revealed that all the teachers who claimed to employ this strategy used a combined set of collaborative teaching activities. A qualitative study done by the same author Rababah (2020) investigated students' attitudes towards the use of Microsoft Teams in their learning. Six EFL students at Jadara University in Jordan were chosen and interviewed using a focus group interview. Three positive themes emerged from students' responses namely, convenience, time efficiency, and shared learning resources. And two negative themes were noted as well including technical problems and difficulties in doing certain types of exercises.

Investigated the effect of gender on attitudes towards learning English is essential. A study done by Malekmahmudi \& Malekmahmudi (2018) explored the effects of gender attitude towards English. The participants of this study were from different universities in Iran majoring in Medical Sciences. The results of this study showed that gender had no effect of attitude, whether it is behavioural, cognitive and emotional attitudes. On the other hand, different studies such as (Kobayashi, 2002; Oxford \& Shearing, 1994) found that female students had higher motivation than male students due to brain hemispheric, socialization, and cognitive style which may play a dynamic role in such differences (Oxford \& Shearing, 1994). In the Jordanian context, different studies such as (Abu-Snoubar, 2017, Al-Khasawneh \& Al-Omari, 2015; Tahaineh \& Daana, 2013) found that female students had higher motivation/attitude than male students. For example, Abu-Snoubar (2017) showed in the result that female students at Al-Balqa Applied University in Jordan proved to be more positive in their attitudes. Another study done by Al-Khasawneh \& Al-Omari (2015) discovered the effect of gender among 51 Jordanian gifted school students in Ajloun governorate. The researcher used (AMTB) questionnaire adapted from gardener's (1985). The results showed that female students had higher motivation than male students.

\subsubsection{Influence of Attitudes to Language Learning}

Learning a language is a process related to forming attitudes towards this language (Starks \& Paltridge, 1996). Gardner (1985) argues that attitudes play an essential role as significant components of motivation in the process of learning a language. He stresses that motivation is a combination of effort and desire to reach a specific objective accompanied by a positive attitude to learn a language. He also argues that preconceived notions and personal traits, such as attitudes towards the other and the will to learn a new language, determine the level of motivation to learn a foreign language (Gardner, 1985).

The impact of attitudes over learning another language is not fully determined and agreed on. Thus, a person with a positive attitude and high motivation towards a language may not learn the language successfully because of the existence of other factors in the learning process. Differences between learners are also another reason that may lead to different learning outcomes (Gardner, 1985).

Researchers such as (Bernat \& Gvozdenko, 2005; and Csizér \& Dornyei, 2005) conclude that attitude is an essential factor in language learning. Many domains of language attitudes have also been studied and investigated. Bernaus, Masgore, Gardner, and Reyes (2004) studied the relationship between attitudes and motivation. Gan (2004) studied the relationship between attitudes and learning strategies. The relationship between attitudes and the level of achievement has also been investigated by Graham (2004). The relationship between beliefs and attitudes and the use of the target language or the first language about anxiety were studied by Levine (2003). In addition to these studies, Yang \& Lau (2003) investigated attitudes to language and language learning at secondary and tertiary levels. The attitudes towards English-language usage among peers have been studied by White (2002). Lindemann (2002) also studied the relationship between the negative attitudes the particular form towards non-native speakers and their poor comprehension. Lee (2001) studied the 
attitudes towards debatable usages between teachers and their students in one study and investigated the attitudes of native speaker teachers and non-native speaker teachers towards disputable usages. Finally, Flaitz (1988) studied the relationship between attitudes towards ideology, culture, people, language and factors affecting attitude. In this study, the researcher of this study is going to focus on different variables such as the gender, language experience and (place) surrounding the learning process with language attitudes among Jordanian EFL learners.

\section{Research Questions}

1- What is the level of language attitudes towards English among tenth-grade students of a private school in Irbid, Jordan?

2- Is there a relationship between gender, age, and place with language attitudes?

\section{Method}

\subsection{Research Design and Instrument}

This study followed the quantitative methodology. The researcher used a questionnaire in his study to achieve its objectives. The first part of the questionnaire covered demographic information of the sample of the study, such as gender, the age the participants started to learn English and the place where they started to learn English. The second part of the questionnaire covered questions about students' attitudes towards English language by using a five-point Likert scale adapted from gardener's (1985) attitude and motivation test battery (AMTB).

\subsection{Participants}

The participants of the study consisted of (300) tenth-grade students from private schools in Jordan, (168) female students and (132) male students, who were chosen randomly. Students start to learn English at the age between less than 6 years or 7 years and above. Regarding the place where they started to learn English, whether at school, pre-school or other places.

\section{Results and Discussion}

The results of this study are based on the objectives of the study, which are to discover the level of language attitudes among Jordanian students and to find out the relationship between language attitudes and various factors. The first section discussed the first objective which investigates the levels of language attitudes. The participants of this study were 300 tenth grade students school in Irbid, Jordan. In addition, Descriptive analysis was used in this study to discover the level of language attitude. The researcher found that Jordanian students in this study reported a medium level of attitude, which is 3.65 .

Table 1: Level of Language Attitudes among Students

\begin{tabular}{lcccc}
\hline & $\mathrm{N}$ & Mean & Std. Deviation & Attitude Level \\
Attitude & 300 & 3.65 & .54394 & Medium \\
Valid N (listwise) & 300 & 3.5 & .54 \\
\hline
\end{tabular}

The second objective is to discover the relationship between language attitudes and different factors such as gender, language experience, and place of learning language . 
Table 2: Variation in Language Attitude According to Gender. (T-test (Independent Sample T-test))

\begin{tabular}{lcccc}
\hline Gender & Mean & Standard Deviation & Significance Level & Level of Use \\
Male $(\mathrm{n}=168)$ & 3.81 & .555 & .047 & Medium \\
Female $(\mathrm{n}=132)$ & 3.94 & .532 & & Medium \\
\hline
\end{tabular}

Based on the first factor, which is gender, the participants of this study were 300 students divided as 168 male students and 132 female students. The researcher randomly selected the participants as the researcher found difficulties to interact with more female students. Some female students refused to be part of the study because of their shyness to contact a male researcher. The researcher used T-test to get the results.

The results revealed statistically significant differences between language attitude and gender. Table 2 shows that female students reported a higher level of language attitude compared to their male counterparts. As shown in Table 2, the mean for a female student is 3.94, and for a male is 3.81 .

Table 3: Variation in Language Attitude According to Language Experience. (T-test (Independent Sample T-test))

\begin{tabular}{lcccc}
\hline Experience & Mean & Standard Deviation & Significance Level & Level of Use \\
Less than $6(\mathrm{n}=162)$ & 2.86 & .555 & .002 & Medium \\
Above $6(\mathrm{n}=138)$ & 3.54 & .532 & .02 & Medium \\
\hline
\end{tabular}

The second factor is language experience. In this study, language experience means when the students start to learn the language. The researcher divided the students into two main parts which are less than 6 years old, and above 7 years old. 162 students started to learn the language when they are less than 6 years, while 138 students started to learn the language when they are above 7 years. The researcher also used T-test to discover whether if there is a significant difference between language attitude and language experience. Students with less than 6 years showed their mean as 2.86, while students who were above 7 years showed their mean as 3.54. Table 2 shows that there is a significant difference between language attitude and language experience.

Table 3: Variation in Language Attitude According to the Place of Learning Language. (ANOVA)

\begin{tabular}{lcccc}
\hline Place & Mean & Standard Deviation & Significance Level & Level of Use \\
Pre-School $(\mathrm{n}=74)$ & 2.98 & .488 & & Medium \\
School $(\mathrm{n}=101)$ & 3.32 & .557 & .035 & Medium \\
Other places $(\mathrm{n}=25)$ & 2.92 & .576 & & Medium \\
\hline
\end{tabular}

The third variable of this study is the place of learning the language. The researcher divided the place into three places: pre-school which represent 74 students, at school, which represent 101 students, other places including families who speak English with their children, and friends included 25 students. The researcher used ANOVA to analyse the data. Table 3 indicates that the three subgroups showed significant differences in language attitude and the place of learning language. The mean for the three groups was almost near from each other's like the mean for pre-school is 2.98 , while the standard deviation is .488. The mean for school learning is 3.32 , while the standard deviation is .557 . The last subgroup is other places, the mean for other places is 2.92 , while the standard deviation is .576 .

\section{Discussion}

This study attempts to encourage the researchers who concern to study students' attitudes towards learning English. In addition to the variables which affected attitudes. 
Concerning the first question: What is the level of language attitudes towards English among tenth-grade students school in Irbid, Jordan? Among 300 students, the participants in this study reported overall attitude is a medium level $(M=3.65, S . D=.54394)$. This result is in line with very few numbers of researches which highlighted the same results, such as Momani (2009). The researcher identified that the level of students' attitude towards English on Jordanian High School students is moderate. The researcher of this study expects the reasons behind the moderate level of attitude are low students' preference to preserve their identity, students think that they might lose their values and traditions if they interact with English societies, and students do not believe that to get a better job, they need to be good enough in English.

In contrast, the results of this study are not consistent with other researchers whom they represent a negative attitude towards learning English. These studies such as Abdin, Mohammadi and Alzwari (2012) found that Libyan students showed a negative attitude towards learning English. Another study done by AL-Zahrani (2008) studied language attitude towards learning English among Saudi students. The participants reported negative attitude because students do not practice English in the right manner, and the methods that the teachers use when they teach English for Saudi students. Besides, the result of this study does not consist with other participants who showed positive attitudes towards learning English such as Al Noursi (2013); AL-Tamimi \& Shuib (2009); Tahaineh \& Dana (2013); Chalak \& Kassaian (2010), Ahmed (2015), Malallah (2010); Kitjaroonchai \& Kitjaroonchai (2012); Che Mat \& Yunus, 2014). The results of these studies were that students showed a positive attitude towards learning English. The researcher of this study believed that the participants of the above studies are aware of the importance of English, so they desire to learn and master their ability in English to succeed in all life fields.

Concerning the first question: Is there a relationship between gender, age, and place with language attitudes? Among 300 students, the participants in this study reported that female students have a more positive attitude towards learning the language more than male does. Students who learned English at pre-school have a more positive attitude compared with others. Students who start to learn the language at the age of 6 and below have more positive attitude than the second group. This result is partially agreed with other studies on gender factor such as Abu-Snoubar (2018); AlKhasawneh \& Al-Omari (2015); Dörnyei (2005); Kobayashi (2002); Shoaib \& Dornyei (2005); Hashwani (2008), Zainol Abidin et al., (2012). Studies that discussed the difference between male and female in acquiring the language reported that female students had a more positive attitude towards learning English than male. A study done by Al-Khasawneh \& Al-Omari (2015) discussed language attitude according to gender. The participants were 51 Jordanian gifted school students in Ajloun. The researchers used a questionnaire to achieve their objectives. The results revealed that female students had a more positive attitude towards learning English than male. Also, Japanese female participants showed a higher positive attitude towards learning English. The reason behind such a result was because of social aspects because Japanese society represents English as an essential career for women's status (Kobayashi, 2002). On the contrary, the result of this research is not agreed with others who declared that male shows more positive attitude than female or those who discovered that gender does not affect language attitude such as Al-Zahrani (2008) Karatas, Alci, Bademcioglu, Ergin, 2016; Soleimani \& Hanafi, 2013).

Other factors which have been studied in this research are language experience and the place of learning the language with language attitude. The participants of this study revealed that students who learned English at pre-school have more positive attitude compared with other groups, students who start to learn the language at the age of 6 and below have more positive attitude than the second group. Among the three factors, the results showed that there is a significant relationship between these factors and language attitude. These three variables were discussed and studied by Karahan (2007) on Turkish students. The results on both researches were almost the same; these variables for students at Jordan and Turkish claimed that female students have a more positive attitude towards learning the language more than male does. Students who learned English at pre-school have a more positive attitude compared with others. Students who start to learn the language at the age of 6 and 
below have a more positive attitude than the second group. They can speak with more confident way than other groups.

\section{Conclusion}

This study discussed the language attitudes among EFL students in Jordan society. The present study aimed to investigate the level of language attitude and to discover the relationship between gender, language experience, and the place of learning the language with language attitude. The participants of this study were 300 tenth school students from a private school in Irbid, Jordan. The researcher analysed his data by using SPSS tool. The results of the study were that the participants have a medium level of language attitude. Female students have a more positive attitude towards learning the language more than male does. Students who learned English at pre-school have a more positive attitude compared with others. Students who start to learn the language at the age of 6 and below have a more positive attitude than the second group. They can speak with a more confident way than other groups.

\section{Acknowledgement}

This research is funded by the Deanship of Research in Zarqad University /Jordan.

\section{References}

Abidin, M, Mohammadi, M. \& Alzwari, H. (2012). EFL Students' Attitudes towards Learning English Language: The Case of Libyan Secondary School Students. Asian Social Science, 8(2), 119-134.http://dx.doi.org/10.5539/ass.v8n2p119

Abu-Snoubar, T, K. (2017). An Evaluation of EFL Students' Attitudes toward English Language Learning in Terms of Several Variables. International Journal of English Language Teaching, 15(6), pp.18-34.

Agheyisi, R. \& Fishman, J. (1970). Language attitudes: A brief survey of methodological approaches. Anthropological Linguistics, 12, 137-157.

Ahmad, S. (2015). Attitudes toward English Language Learning among EFL Learners at UMSKAL. Journal of Education and Practice, 6(18), 6-16.

Akere, F. (1981). Functional Variation and the Communicative use of English in Nigeria. A paper presented at the international conference on African Literature and the English Language. University of Calabar, Nigeria.

Al Bataineh, K., B. (2019). English Language Learning Beliefs of Jordanian Students: The Effect of Gender. International Journal of English Linguistics, 9(2), 219-228. doi:10.5539/ijel.v9n2p219

Al-Khatib, M. (1995). A sociolinguistic View of Linguistic Taboo in Jordanian Arabic. Journal of Multilingual and Multicultural Development, 16(6), 443-457.

Al Noursi, O. (2013). Attitude towards Learning English: The case of the UAE Technological High School. Educational Research, 4(1), 21-30.

Al Samadani, H.\&Ibnian. S. (2015). The Relationship between Saudi EFL Students' Attitudes towards Learning English and their Academic Achievement.InternationalJournal of Education and Social Science, 2(1), 92- 102.

Al- Tamimi, A. \&Shuib, M. (2009). Motivation and Attitudes Towards Learning English: A Study of Petroleum Engineering Undergraduates at Hadhramout University of Scienceand Technology. GEMA Online Journal of Language Studies, 9(2), 29-50.

Al-Khasawneh, F, M. \& Al-Omari, M, A. (2015). Motivations towards Learning English: The Case of Jordanian Gifted Students. International Journal of Education, 7(2), 306- 321.

Al-Khasawneh, F, M. \&Huwari, I. (2020). A Correlational Study of the Relationship between Morphological Awareness and Vocabulary Knowledge of Saudi EFL Learners.Journal of ELT Research,5(2),1-15. DOI: 10.22236/JER

Al-Zahrani, M. (2008). Saudi secondary school male students' attitudes towards English: An exploratory study. J. King Saudi University, Language and translation, 20, 25-39.

Assaf, A.S. (2001). Palestinian students' attitudes towards Modern Standard Arabic and Palestinian City Arabic, RELC Journal, 32(2), 45-62.

Baker, C. (1992). Attitudes and Language. Multilingual Matters 83. Clevendon, Avon, England: Multilingual Matters. 
Bernat, E. and Gvozdenko, I. (2005). Beliefs about language learning: Current knowledge, pedagogical implications, and new research directions. TESL EJ, 9(1), 1-21.

Bernaus, M., Masgore T, A.M., Gardner, R. C., and E. Reyes. (2004). Motivation and attitudes towards learning languages in multicultural classrooms. The International Journal of Multilingualism, 1(2), 75-89.

Buschenhofen, P. (1998). English language attitudes of final-year high school and first-year university students in Papua New Guinea, Asian Journal of English Language Teaching, 8, 93-116.

Chalak, A. \& Kassaian, Z. (2010). Motivation and Attitude of Iranian Undergraduate EFL Students towards Learning English. GEMA Online Journal of Language Studies, 10(2), 36-57.

Che Mat, S., \& Yunus, M. (2014). Attitudes and motivation towards learning English among FELDA school Students. Australian Journal of Basic and Applied Sciences, 8(5), 1- 8.

Crystal, D. (200o). Language death. Cambridge, England: Cambridge University Press.

Csizér, K. and Dornyei, Z. (2005). The internal structure of language learning motivation and its relationship with language choice and learning effort. The Modern Language Journal, 89(i), 19-36.

Dörnyei, Z. (2005). The psychology of the language learner: Individual differences in second language acquisition. Mahwah, NJ: Lawrence Erlbaum.

Fishman, J., A. (1972). The Sociology of Language. Rowley, MA.: Newbury House.

Flaitz, J. The Ideology of English: French Perceptions of English as a World Language (Berlin: Mouton de Gruyter, 1988).

Gan, Z. Attitudes and strategies as predictors of self-directed language learning in an EFL context. International Journal of Applied Linguistics, 14(3), 389-411.

Graham, S. J. (2004). Giving up on modern foreign languages? Students' perceptions of learning French. The Modern Language Journal, 88, 171-191.

Gardner, R. C. (1985). Social psychology and second language learning: the role of attitudes and motivation. London: Edward Arnold.

Garrett, P. (2010). Attitudes to language. Cambridge: Cambridge University Press.

Hashwani, M., S. (2008). Students' attitudes, motivation and anxiety towards English language learning. Journal of Research and Reflections in Education, 2(2), 121-144.

Holmes, J., Roberts, M., Verivaki, M., and Aipolo, A. (1993). Language maintenance and shift in three New Zealand speech communities. Applied Linguistics,14 (1). Available at: http://applij.oxfordjournals.org/content /14/1/1.full.pdf+html

Isabelli-García, C. (2006). Study abroad social networks, motivation and attitudes: implications for second language acquisition. In M. A. DuFon and E. Churchill (Eds.), Language learners in study abroad contexts. Clevedon: Multilingual Matters, 231-258.

Kansikas, M. (2002)."As many men, so many minds": a study on attitudes towards foreign languages in Finland. Master's thesis. University of Jyväskylä, Department of Languages. http://urn.fi/URN:NBN:fi:jyu2002893230.

Karahan, F. (2007). Language attitudes of Turkish students towards the English language and its use in Turkish context. Journal of Arts and Sciences, 7, 73-87.

Karatas H, Alci B, Bademcioglu M, Ergin A. (2016). Examining University Students' Attitudes towards Learning English Using Different Variables. International Journal of Educational Researchers, 7(3), 12-20.

Kitjaroonchai, N., \& Kitjaroonchai, T. (2012). Motivation toward English language learning of Thai students majoring in English at Asia-Pacific International University. Catalyst, 7(1), 21-40.

Kobayashi, Y. (2002). The role of gender in foreign language learning attitudes: Japanese female students' attitudes towards English learning. Gender and Education, 14(2), 181-197. http://dx.doi.org/10.108o/o9540250220133021

Krauss, M. (1992). The world's languages in crisis.Language, 68, 4-10.

Lee, J.F.K. (2001), Attitudes towards debatable usages among English language teachers and students. Journal of Applied Linguistics, 6(2), 1-21.

Leppänen, S., Pitkänen-Huhta, A., Nikula, T., Kytölä, S., Törmäkangas, T., Nissinen, K., Kääntä, L., Räisänen, T., Laitinen, M., Pahta, P., Koskela, H., Lähdesmäki, S. and Jousmäki, H. (2011). National Survey on the English Language in Finland: uses, meanings and attitudes. Studies in Variation, Contacts and Change in English. Helsinki: University of Helsinki.

Llurda, E. (2009). Attitudes towards English as an international language: the pervasiveness of native models among L2 users and teachers. In F. Sharifian (Ed.), English as an international language: perspectives and pedagogical issues. Bristol: Multilingual Matters, 119-134.

Levine, G.S. (2003). Student and instructor beliefs and attitudes about target language use, first language use and anxiety: Report of a questionnaire study, The Modern Language Journal, 87(3), 343-364. 
Lindemann, S. (2002). Listening with an attitude: A model of native-speaker comprehension of non-native speakers in the United States. Language in Society, 31(3), 419-41.

Malallah, S. (2010). English in an Arabic Environment: Current Attitudes to English Among Kuwait University Students. International Journal of Bilingual Education and Bilingualism, 3(1), 19-43. http://dx.doi.org/10.1080/13670050008667698

Malekmahmudi, M., K. \& Malekmahmudi, S., K. (2018). Attitude of Iranian Students towards Learning the English Language. Journal of Clinical and Basic Research (JCBR), 2(2), PP. 35-39.

Malessa, E. (2011). Friend or foe?: Attitudes to and beliefs about English in Finland expressed by Finnish as a second language learners. Master's thesis. University of Jyväskylä, Department of Languages. https://jyx.jyu.fi/dspace/handle/123456789/26617.

Oladunni, D. (2016). Language Use and Language Attitudes in a Bi/Multilingual Community: An Overview. International Journal of Innovative Language, Literature $\mathcal{E}$ Art Studies, 4(1), 51-56.

Oxford, R., \& Shearing, J. (1994). Language learning motivation: Expanding the theoretical framework. Modern Language Journal, 78, 12-28. http://dx.doi.org/10.1111/j.1540-4781.1994.tbo2011.x

Oyetade, S. O. (2002). Language Policies and Planning in Nigeria in Research in African Language and Linguistics. 6, 51-66

Rababah, 1., M. (2019). Using Collaborative Learning Strategies to Improve Creativity in EFL Writing: Attitudes and Actual Use. Journal of Education in Black Sea Region, 5(1), 69-76. Doi: 10.31578/jebs.v5i1.189

Rababah, 1., M. (2020). Jadara University Students' Attitudes towards the Use of Microsoft Teams in Learning English as a Foreign Language. Studies in Linguistics and Literature, 4(4), 59- 64. doi:10.22158/sll.v4n4P59

Saidat, A, M. (2010). Language Attitude: The Case of Jordan. International Journal of Academic Research, 2(6), 235243.

Shoaib A, Dornyei Z. (2005). Affect in lifelong learning: exploring L2 motivation as a dynamic process. From Learners' stories: difference and diversity in language learning. Ed. Benson, P. \&Nunan, D. Cambridge University Press. 22- 41.

Soleimani H, \& Hanafi S. (2013). Iranian medical students' attitudes towards English language learning. International Research Journal of Applied and Basic Sciences, 4(12), 3816-3823.

Starks, D. and Paltridge, B. (1996). A note on using sociolinguistic methods to study non-native attitudes towards English. World Englishes, 15 (2), pp. 217-224.

Tahaineh, Y. \&Daana, H. (2013). Jordanian Undergraduates' Motivations and Attitudes towards Learning English in EFL Context. International Review of Social Sciences and Humanities, 4(2), 159-180.

White, C.M. (2002). Language authenticity and identity: Indigenous Fijian students and language use in schools, Language, Culture and Curriculum, 15(1), 16-29.

Yang, A. \& Lau, L. (2003). Student attitudes to the learning of English at secondary and tertiary levels, System, 31(1), 107-123.

Yağmur, K. (1997). First Language Attrition among Turkish Speakers in Sydney. The Netherlands: Tilburg University Press.

Zhang, D., and Slaughter-Defoe, D. (2009). Language attitudes and heritage language maintenance among Chinese immigrant families in the USA. Language, 